\title{
ANALISIS MERKURI MENGGUNAKAN 4,4'-BIS(DIMETHYLAMINO)THIO-BENZOPHENONE SECARA SPEKTROFOTOMETRI DI PERAIRAN LOANG BALOQ, TANJUNG KARANG
}

\section{ANALYSIS OF MERCURY USING 4.4'-BIS (DIMETHYLAMINO) THIO-BENZOPHENONE SPECTROFOTOMETRY IN LOANG BALOQ BASIN, TANJUNG KARANG}

\author{
Muti’ah*, Syarifa Wahida Al Idrus, Sukib \\ Program Studi Pendidikan Kimia, Jurusan pendidikan MIPA, Fakultas Keguruan dan Ilmu Pendidikan, \\ Universitas Mataram \\ *Email: mutiah_fkip@unram.ac.id
}

Diterima: 11 Desember 2018. Disetujui: 06 Februari 2019. Dipublikasikan: 31 Maret 2019

\begin{abstract}
Abstrak: Merkuri merupakan unsur paling toksik, oleh karena itu keberadaanya di lingkungan perlu diketahui secara pasti. Perairan lokasi wisata Loang Baloq Tanjung karang merupakan muara suangai yang diduga membawa limbah yang mengandung merkuri. Tujuan penelitian ini adalah untuk mengetahui distribusi logam merkuri dalam air dan sedimen di Lokasi Perairan Wisata Loang Baloq. Langkah-langkah yang dilakukan adalah pengambilan sampel, preparasi sampel, reaksi pembentukan kompleks merkuri-4,4'Bis(dimethylamino)thio-benzophe-none, pengukuran dengan spektrofoto-meter uv-vis. Hasil analisis menunjukan bahwa distribusi konsentrasi merkuri baik dalam air mupun sedimen di lokasi wisata Loang Baloq bervariasi. Konsentrasi merkuri dalam air kolam antara $0,0110 \mathrm{~s} / \mathrm{d} 0,0310 \mathrm{mg} / \mathrm{L}$, air sungai hilir sebesar 0,0082 $\mathrm{s} / \mathrm{d}$ 0,0254 mg/L dan air muara sebesar $0,0004 \mathrm{~s} / \mathrm{d} 0,0179 \mathrm{mg} / \mathrm{L}$. Konsentrasi merkuri dalam sedimen kolam antara 2,560 s/d 4,542 mg/kg, sedimen sungai hilir sebesar 1,668 s/d 3,217 mg/kg, dan sedimen muara sebesar $1,203 \mathrm{~s} / \mathrm{d} 2,039 \mathrm{mg} / \mathrm{kg}$. Kesimpulan yang diperoleh dari penelitian ini menunjukan bahwa distribusi merkuri baik dalam air maupun sedimendi lokasi Perairan Loang Baloq tidak merata.
\end{abstract}

Kata kunci: analisis, merkuri, 4,4'-Bis(dimethylamino)thio-benzophenone, spektrofotometri

\begin{abstract}
Mercury is the most toxic element, therefore its presence in the environment needs to be known precisely. The Loang Baloq area of Tanjung Karang is a river estuary that is thought to carry waste containing mercury. The purpose of this study was to determine the distribution of mercury in water and sediment in the area of Loang Baloq. The steps taken are sampling, sample preparation, the 4,4'-Bis (dimethylamino) thiobenzophe-none complex mercury formation reaction, measurement with uv-vis spectrophotometer. The results of the analysis show that the distribution of mercury concentrations in both water and sediment in the Loang Baloq area is varied. The concentration of mercury in pond water is between 0.0110 to $0.0310 \mathrm{mg} / \mathrm{L}$, downstream river water is 0.0082 up to $0.0254 \mathrm{mg} / \mathrm{L}$ and estuarine water is 0.0004 to $0.0179 \mathrm{mg} / \mathrm{L}$. The concentration of mercury in pond sediments is 2.560 to $4.542 \mathrm{mg} / \mathrm{kg}$, downstream river sediments are 1,668 to $3,217 \mathrm{mg} / \mathrm{kg}$, and estuary sediments are 1.203 to $2.039 \mathrm{mg} / \mathrm{kg}$. The conclusions obtained from this study indicate that the distribution of mercury in both water and sediments in the Loang Baloq area is uneven.
\end{abstract}

Kata kunci: analysis, mercury, 4,4'-Bis(dimethylamino)thio-benzophenone, spectrophotometry

\section{PENDAHULUAN}

Pantai Loang Baloq adalah sebuah pantai berpasir yang merupakan bagian dari Pantai Tanjung Karang di bagian barat Kota Mataram. Pantai ini banyak dikunjungi wisatawan dan peziarah karena selain dilengkapi dengan taman kolam (danau buatan), lokasi pantai Loang Baloq juga berada di komplek pemakaman Maulana Syech Gaus Abdurrazak, datuk laut dan anak yatim. Kolam yang dijadikan obyek wisata tersebut merupakan kolam buatan dimana sumber airnya berasal dari air sungai Telabah yang bermuara di Pantai Loang Baloq tersebut.
Kondisi fisik air sungai tersebut sudah cukup kotor, karena sungai tersebut mengalir melewati daerah perkotaan, perumahan, pasar, peternakan, bahkan industri rumah tangga, sehingga sungai tersebut menerima beban limbah yang cukup besar. Selain itu di daerah Sekarbela pernah menjadi tempat penggelondongan emas tradisional yang menggunakan merkuri. Sementara aliran air buangan di daerah tersebut mengalir ke Sungai Telabah. Oleh karena itu perlu dilakukan penelitian bagaimana keberadaan merkuri di perairan tersebut.

Merkuri merupakan unsur yang berbahaya baik dalam bentuk uap $\mathrm{Hg}^{\mathrm{o}}$, ion $\mathrm{Hg}^{2+}$, maupun 
organo-merkuri (metilmerkuri $\mathrm{CH}_{3} \mathrm{Hg}^{+}$, etilmerkuri $\mathrm{C}_{2} \mathrm{H}_{5} \mathrm{Hg}^{+}$, fenilmerkuri). Sifat toksik merkuri pada manusia dapat menyebabkan bronkitis akut, kerusakan ginjal, neorotoksis, hiposensitif, depresi, koma, dan kematian [1]. Oleh karena itu deteksi metil merkuri dalam pangan dan lingkungan sangat diperlukan.

Lingkungan di lokasi Wisata Loang Baloq yang perlu untuk diketahui jumlah dari kandungan merkuri terutaman adalah air sungai yang berada di hilir, air kolam (danau buatan) dan muara (air sungai campur dengan air laut). Perbedaan lokasi yang dipilih sebagai sampel adalah mengingat bahwa air kolam Loang Baloq menggunakan air Sungai Telabah tanpa melalui proses pengolahan, sehingga diduga bahan pencemar akan terakumulasi di perairan tersebut.

Dari hasil kejian literatur dinyatakan bahwa analisis merkuri dapat dilakukan dengan menggunakan metode GC-AFS, HPLC-ICP MS, dan GC-AE [2]. Namun metode tersebut memerlukan peralatan mahal, biaya perawatan tinggi dan keahlian khusus [3]. Oleh sebab itu sulit terjangkau oleh laboratorium di negara berkembang apalagi laboratorium di daerah.

Analisis merkuri secara spektrofotometri, cukup memerlukan biaya peralatan relatif murah dan cara kerjanya sederhana, tetapi membutuhkan proses kimiawi secara spesifik. Niazi dan kawankawan mendeteksi merkuri menggunakan teknik spektrofotometri secara langsung dengan pereaksi thio Michler's ketone TMK (4,4'-Bis(dimethylamino)thio-benzophenone) [4]. Kendala yang dihadapi adalah sensitivitas rendah, namun telah diatasi oleh [2].

Sukib dan Muti'ah juga telah meneliti gangguan matriks dalam analisis merkuri dengan menggunakan pengekstrak eter [5]. Hasil penelitian dalam skala laboratorium menunjukan bahwa eter mamapu mengekstrak senyawa kompleks selain merkuri. Namun demikian penelitian tersebut belum diterapkan dalam sampel secara luas, sehingga perlu dilakukan penelitian lanjutan mengenai penerapan metode tersebut dalam sampel nyata di lingkungan. Berdasarkan fakta di atas, maka permasalaha yang perlu diungkap adalah: (1) Berapa rentang konsentrasi merkuri di perairan obyek wisata Loang Baloq (2) Bagaimana distribusi merkuri di perairan obyek wisata Loang Baloq (muara, sungai, dan kolam). Tujuan dari penelitian ini adalah untuk mengetahui distribusi logam merkuri dalam air dan sedimen di Lokasi Perairan Wisata Loang Baloq, Tanjung Karang.

\section{METODE PENELITIAN}

\section{Peralatan dan Bahan Kimia}

Peralatan yang digunakan terutama adalah Spektrofotometer Uv-Vis Perkin-Elmer Lamda 45 Uv-Vis., $\mathrm{pH}$ meter, water bath, sentrifugasi, dan peralatan gelas (labu takar, pipet volum, dan lainlain).

Bahan yang digunakan semuanya berkualitas pa., yaitu $1000 \mathrm{ml}$ larutan stok ion logam: $\mathrm{Hg}(\mathrm{II}), \mathrm{Cu}(\mathrm{II}), \mathrm{Ag}(\mathrm{I}), \mathrm{Pt}(\mathrm{II}), \mathrm{Au}(\mathrm{III}), \mathrm{Co}(\mathrm{II})$, $\mathrm{Ni}(\mathrm{II}), \mathrm{Fe}(\mathrm{II})$ masing-masing $1000 \mathrm{mg} / \mathrm{L}$. Pereaksi Thio Michler's Ketone (TMK)/4,4'Bis(dimethylamino)thiobenzophe-none, Dietil eter, $\mathrm{NaCl}, \mathrm{H}_{2} \mathrm{SO}_{4}, \mathrm{HNO}_{3}, \mathrm{HCl}$, etanol, natrium asetat, asam asetat glasial, dietil eter, dan kertas saring.

\section{Sampel}

Sampel (air, sedimen) diambil di Lokasi Perairan Wisata Loang Baloq, yaitu lokasi kolam, muara, dan sungai. Jumlah sampel yang diambil sebanyak 30 sampel air dan 10 sampel sedimen.

\section{Preparasi Sampel}

Preparasi sampel baik air maupaun sedimen mengacu pada Ramalhosa dan kawan-kawan [6]. Untuk sampel air, sebanyak $100 \mathrm{ml}$ sampel air disaring dengan kertas whatman No. 40. Hasil saringan ditambah $5 \mathrm{ml} \mathrm{HNO}_{3}$ pekat dan $1 \mathrm{ml}$ $\mathrm{KMnO}_{4} 1 \%$, kemudian dididihkan 10 menit. Volume ditepatkan $100 \mathrm{ml}$ dengan akua bebas mineral untuk siap dianalisis.

Untuk sampel sedimen, sebanyak sekitar 50 gram dikeringkan udara, kemudian diambil 0,5 gram dan didestruksi dengan $10 \mathrm{ml}$ akuregia $\left(\mathrm{HNO}_{3}-\mathrm{HCl}\right)$, selanjutnya dilarutkan dalam akua bebas ion dan ditambah $1 \mathrm{ml} \mathrm{KMnO}_{4} \quad 1 \%$ dapanasakan 10 menit dan volume ditepatkan sampai $100 \mathrm{ml}$, sampel siap dianalisis.

\section{Analisis Kimia/Pengukuran}

Penelitian ini akan dilakukan di Laboratorium Kimia, FKIP Unram dan Lab. Kimia Analitik FMIPA Unram. Prosedur kerja penelitian ini secara umum mengacu penelitian tahun (Sukib dan Muti'ah, 2016) dengan kondisi sebagai berikut: $\lambda \max 574 \mathrm{~nm}$; pH 3; konsentrasi TMK 0,0002 M, dan waktu tunggu selama 4-10 menit. linieritas 0,05-2,0 $\mathrm{mg} / \mathrm{L}$, Formula perbandingan volume pereaksi $\mathrm{Hg}(\mathrm{II})$, bufer $\mathrm{pH} 3$, TMK 0,002 M, $\mathrm{H}_{2} \mathrm{O}$ bebas ion adalah: $1: 1: 1: 7$. Selanjutnya diekstrak dengan dietil eter, fase air selanjutnya diukur absorbansinya pada $\lambda \max$.

\section{Analisis Data}

Data kadar merkuri dari hasil analisis 3.4 dilakukan dengan menggunakan statistik uji-t dan diselesaikan dengan komputer program Excell [7]. Data kadar merkuri dianalisis secara deskriptif dan disajikan dalam bentuk tabel dan diagram.

\section{HASIL DAN PEMBAHASAN}

Untuk mengetahui distribusi merkuri di lokasi perairan Loang Baloq, maka telah dilakukan sampling untuk air dan sedimen masing-masing di lokasi hilir sungai, muara sungai, dan di kolam. Beberapa pertimbangan dalam pengambilan sampel adalah sebagai berikut: di daerah hilir diharapkan 
peneliti akan menemu-kan data kadar merkuri asli dalam air sungai tersebut, di lokasi muara air sungai telah terencerkan oleh laut. Untuk lokasi kolam diharapkan peneliti akan menemukan kandu-ngan merkuri yang telah mengalami akumulasi di perairan kolam tersebut

Berdasarkan gambar tersebu, maka dapat ditunjukan bahwa pengambilan sampel air di lakukan di 3 lokasi dengan jumlah titik sampling masing-masing lokasi sebanyak 10 sampel air dan 5 sampel untuk sedimen.

Untuk mendapatkan distribusi kadar merkuri $\mathrm{Hg}$ dalam sampel dan sedimen di lokasi tersebut, maka dilakukan langkah-langkah, preparasi sampel, reaksi kimia (mereaksikan antara ion merkuri $\mathrm{Hg}(\mathrm{II})$ dengan pereaksi TMK, penentuan kondisi optimum reaksi dan pengukuran menggunakan spektrofotometer. Dalam artikel ini preparasi sampel sedimen dilakukan dengan menggunakan pelarut campuran $\mathrm{HCl}$ dan $\mathrm{HNO}_{3}$ dengan perbandingan $3: 1$, sedangkan untuk sampel air digunakan $\mathrm{HNO}_{3} \quad 1 \%$. Teknik ini sesuai dengan proses preparasi sampel yang dilakukan oleh peneliti terdahulu [3]. Jumlah sampel air yang digunakan sebanyak $100 \mathrm{ml}$ per sampel, sedangkan untuk sedimen digunakan 0,5 gram berat kering. Dalam penelitian ini menggunakan berat sampel lebih besar dibandingkan dengan penelitin terdahulu yang pada umumnya menggunakan berat sampel antara 0,2-0,5 gram [5]

\section{Serapan Maksimum Senyawa Kompleks Merkuri-4,4'Bis(dimethylamino) \\ Dari hasil preparasi sampel diharapkan} seluruh spesi merkuri yang ada dalam sampel telah membentuk ion merkuri atau $\mathrm{Hg}^{2+}$. Selanjutnya dalam bufer asetat kondisi $\mathrm{pH} 3$ dengan adanya senyawa Thio Michels's Ketone atau 4,4'Bis(dimethylamino)thio-benzophenone maka ion $\mathrm{Hg}$ (II) akan bereaksi membentuk senyawa kompleks yang berwarna biru kehijauan dari Hg-TMK

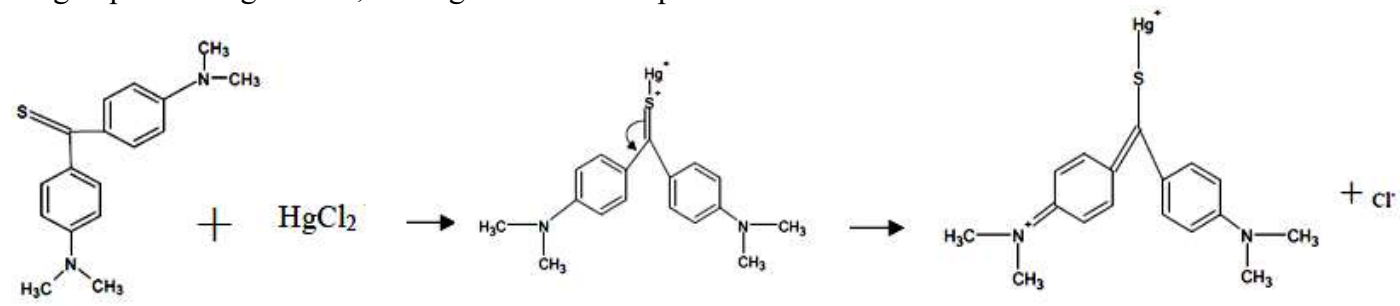

Untuk mendeteksi spektrum senyawa tersebut, selanjutnya dilakukan pengukuran dengan kondisi mengacu pada peneliti terdahulu (Sukib dan Muti;ah, 2016), yaitu: $\mathrm{pH} 3$; konsentrasi TMK 0,0002 M, dan waktu tunggu selama 4-10 menit.
Perbandingan volume pereaksi: $\mathrm{Hg}(\mathrm{II})$, bufer $\mathrm{pH} 3$, TMK $0,002 \mathrm{M}, \mathrm{H}_{2} \mathrm{O}$ bebas ion adalah: $1: 1: 1: 7$. Hasil pengukuran spektrum molekul senyawa $\mathrm{Hg}$ TMK atau merkuri-4,4'Bis (dime-thylamino) thio benzophenone disajikan dalam gambar 1 .

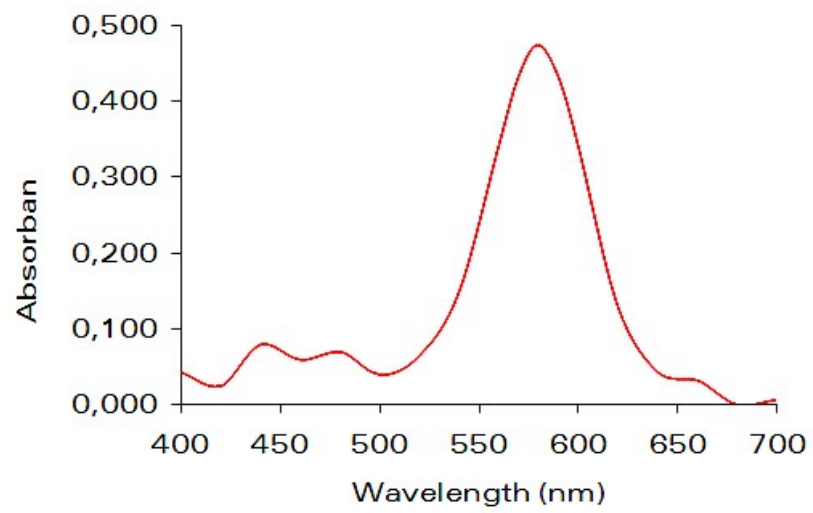

Gambar 1. Spektrum Senyawa merkuri -4,4'-Bis(dimethylamino) thio benzophenone

Berdasarkan spektrum pada gambar 1 menunjukan bahwa senyawa kompleks merkuri-4,4'Bis (dimethylamino) memberikan serapan maksimum pada $\lambda$ sekitar $570 \mathrm{~nm}$. Nilai serapan maksium yang dipublikasikan dalam artikel ini berdekatan dengan nilai maksimum yang ditemukan oleh peneliti terdahulu [8],[9],[4]. Serapan maksimum ini selanjutnya dijadikan dasar dalam pengukuran absorbansi larutan yang mengandung merkuri baik larutan standar maupun larutan sampel.

\section{Kurva Regresi Larutan Standar}

Kurva regresi standar atau kurva larutan standar dalam analisis kimia secara spektrofotometri merupakan bagian yang tidak 
terpisahkan. Dari kurva tersebut dapat diinformasikan dua informasi yaitu untuk membuktikan apakah singal yang diperoleh dari alat ukur tersebut masih bersifat linier antara

konsentrasi dan absorban, ke dua adalah sebagai dasar perhitungan dalam mengkonversi antara singal absorban menjadin konsentrasi [7]

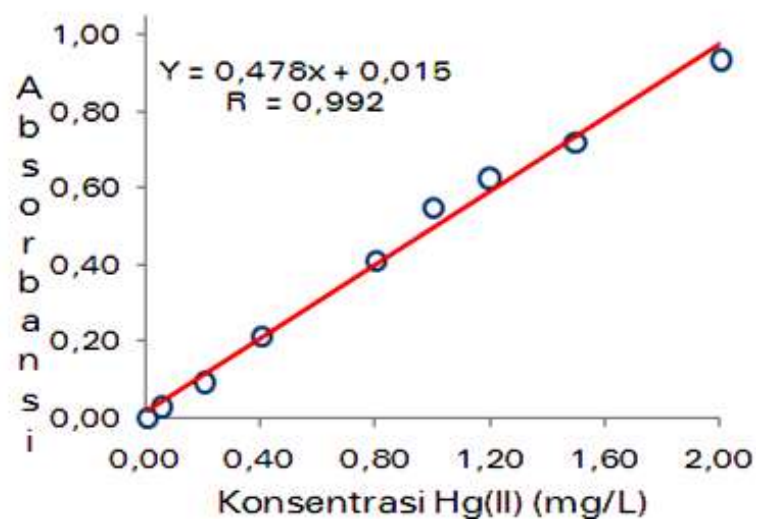

Gambar 2. Kurva Regresi Standar Hg(II)-TMK

Gambar 2 menunjukan bahwa kurva hubungan antara konsentrasi $\mathrm{Hg}$ terhadap absorban bersifat linier pada daerah konsentrasi antara $0 \mathrm{~s} / \mathrm{d}$ $2 \mathrm{mg} / \mathrm{L}$ dengan persamaan $\mathrm{Y}=0,478 \mathrm{X}+0,015$, dengan $\mathrm{R}^{2}$ sebesar 0,992atau $\mathrm{r}=0,996$. Hasil penelitian ini menunjukan nilai $r$ yang cukup tinggi sebagaimana dilaporkan oleh Niazi dan kawankawannya [4]. Selanjutnya dari kurva tersebut digunakan dalam perhitungan konsentrasi sampel hasil pengukuran.

Distribusi Konsentrasi Merkuri dalam Air di Lokasi Loang Baloq

Sampel air yang di teliti di lokasi Loang Baloq adalah di daerah hilir sungai, muara, dan kolam. Di setiap lokasi diambil 10 titik sampel dengan pertimbangan untuk daerah hilir diharapkan dapat mengungkap distribusi merkuri dalam sungai sebelum adanya faktor luar. Sampel air di muara diharapkan dapat mengungkap konsentrasi merkuri dalam air sungai setelah adanya pengenceran dari air laut. Sampel air kolam diharapkan dapat mengungkap konsentrasi merkuri dalam air sungai yang telah mengalami proses fisik maupun kimia termasuk pemekatan. Distribusi kandungan merkuri dalam air di lokasi Loang Baloq disajikan dalam tabel 1.

\section{Tabel 1. Konsentrasi Merkuri Hg dalam Sampel Air}

\begin{tabular}{lll}
\hline No & Sampel & Konsentrasi \\
\hline 1 & Air Sungai Hilir & $0,0082 \mathrm{mg} / \mathrm{L}-0,0254 \mathrm{mg} / \mathrm{L}$ \\
2 & Air Muara & $0,0004 \mathrm{mg} / \mathrm{L}-0,0179 \mathrm{mg} / \mathrm{L}$ \\
3 & Air Kolam & $0,0110 \mathrm{mg} / \mathrm{L}-0,0310 \mathrm{mg} / \mathrm{L}$ \\
\hline
\end{tabular}

Tabel 2. Ringkasan Anava A Konsentrasi Merkuri Hg dalam Air Sungai Hilir, Muara, dan Kolam

\begin{tabular}{lccccc}
\hline Sumber Varian & JK & db & RJK & Fh & Ft 5\% \\
\hline Antar A & 0,001 & 2 & 0,000436 & 2,985 & 3,320 \\
Dalam & 0,004 & 27 & 0,000146 & & \\
Total & 0,005 & 29 & & & \\
\hline
\end{tabular}

Berdasarkan data yang tercantum dalam tabel 1 menunjukan bahwa konsentrasi merkuri tertinggi terdapat dalam air kolam, yaitu antara $0,0110 \mathrm{~s} / \mathrm{d}$ 0,0310 $\mathrm{mg} / \mathrm{L}$ kemudian diikuti sampel air sungai hilir sebesar $0,0082 \mathrm{~s} / \mathrm{d}$ 0,0254 mg/L dan terendah adalah air sungai di muara yaitu sebesar 0,0004 s/d 0,0179 mg/L. Perbedaan konsentrasi Hg di tiga lokasi tersebut disebabkan oleh faktor pemekatan, yaitu air muara merupakan air sungai yang telah terncerkan oleh air laut. Air kolam 
merupakan air sungai yang terkumpul dalam kolam, sehingga dapat mengalami akumulasi ionion logam yang terlarut.

Apabila dibandingkan dengan hasil penelitian di Spanyol maka untuk air sungai ditemukan sebesar $<0,0011 \mathrm{~s} / \mathrm{d} \quad 0,0203 \mathrm{mg} / \mathrm{L}$ [10]. Selanjutnya peneliti yang lain Gray dan kawankawan menemukan antara $0,000-0,013 \mathrm{mg} / \mathrm{L}$ [11], Loredo dan kawan-kawan menemuan kurang dari $0,0005 \mathrm{mg} / \mathrm{L}$ [12], Hovart dan kawan-kawan menemukan 0,005 mg/L [13], Qiu dan kawankawan menemukan $0-0,06 \mathrm{mg} / \mathrm{L}$ untuk sungai di China [14], serta Zhang dan kawan-kawan menemukan $0-0,0036 \mathrm{mg} / \mathrm{L}$ [15]. Dari hasil penelitian terdahulu menjelaskan bahwa perbedaan distribusi merkuri dalam air dipengaruhi oleh faktor $\mathrm{pH}$, materi partikulat dalam air, laju aliran sungai, dan kondisi redoks [16]

Untuk dapatkan informasi apakah konsentrasi merkuri dalam air dari ketoga lokasi, yaitu hilir, muara dan kolam memiliki perbedaan secara signifikan, maka berikut ini disajikan ringkasan Anava A dalam tabel 2.
Berdasarkan data pada tabel 2 menunjukan bahwa konsentrasi merkuri $\mathrm{Hg}$ dalam air dari ketiga lokasi adalah tidak berbeda secara signifikan. Namun apabila diuji lanjut menggunkan uji $\mathrm{t}$ maka untuk lokasi kolam dengan muara berbeda secara signifikan.

\section{Distribusi Konsentrasi Merkuri dalam Sedimen di Lokasi Loang Baloq}

Sampel sedimen yang diambil sesuai dengan lokasi pengambilan sampel air, yaitu daerah hilir sungai, muara, dan kolam. Di setiap lokasi diambil 5 titik sampel dengan pertimbangan untuk daerah hilir diharapkan dapat mengungkap distribusi merkuri dalam sedimen sungai yang berupa lumpur. Sampel sedimen muara sifatnya berbeda karena berpasir, sedangkan sedimen kolam merupakan lumpur yang memungkinkan terjadinya akumulasi ion-ion logam termasuk merkuri. Distribusi kandungan merkuri dalam sedimen di lokasi Loang Baloq disajikan dalam tabel 2.

Tabel 2. Konsentrasi Merkuri Hg dalam Sampel Sedimen

\begin{tabular}{lll}
\hline No & Sampel & Konsentrasi \\
\hline 1 & Sedimen Sungai Hilir & $1,668 \mathrm{mg} / \mathrm{kg}-3,2168 \mathrm{mg} / \mathrm{kg}$ \\
2 & Sedimen Muara & $1,203 \mathrm{mg} / \mathrm{kg}-2,039 \mathrm{mg} / \mathrm{kg}$ \\
3 & Sedimen Kolam & $2,56 \mathrm{mg} / \mathrm{kg}-4,542 \mathrm{mg} / \mathrm{kg}$ \\
\hline
\end{tabular}

Tabel 3. Ringkasan Anava A Konsentrasi Hg dalam Sedimen Sungai Hilir, Muara, dan Kolam

\begin{tabular}{lccccc}
\hline Sumber Varian & JK & db & RJK & Fh & Ft 5\% \\
\hline Antar A & 10,367 & 2 & 5,183 & $7,296^{*}$ & 3,680 \\
Dalam & 8,526 & 12 & 0,710 & & \\
Total & 18,892 & 14 & & & \\
\hline
\end{tabular}

Berdasarkan data yang tercantum dalam tabel 2 menunjukan bahwa konsentrasi merkuri tertinggi terdapat dalam sedimen kolam, yaitu antara 2,560 s/d 4,542 $\mathrm{mg} / \mathrm{kg}$ kemudian diikuti sampel sedimen sungai hilir sebesar 1,668 s/d $3,217 \mathrm{mg} / \mathrm{kg}$ dan terendah adalah air sungai di muara yaitu sebesar 1,203 s/d 2,039 $\mathrm{mg} / \mathrm{kg}$. Perbedaan konsentrasi $\mathrm{Hg}$ di tiga lokasi tersebut disebabkan oleh faktor pemekatan, yaitu sedimen muara merupakan sedimen yang telah tercuci oleh air laut. Sedimen kolam merupakan sedimen yang merupakan hasil akumulasi endapan air sungai yang diduga mengandung kation-kation logam.

Beberapa penelitian telah melaporkan hasil penelitiannya, misalnya Berzas dan kawankawan menemukan kandungan merkuri dalam sedimen sekitar 5,5-1005 mg/kg [17], Biester dan kawan-kawan menemukan kadar merkuri antara 0,13-1229 $\mathrm{mg} / \mathrm{kg}$ [18]. Covelli dan kawan-kawan menemukan sekitar 0,10-23,30 mg/kg [19] dan Suchanek dan kawan-kawan menemukan konsentrasi merkuri total sekitar $<1,0-438 \mathrm{mg} / \mathrm{kg}$ [20]. Hasil penelitian yang dilaporkan peneliti tersebut relatif jauh lebih tinggi, karena penelitian tersebut dilakukan dilokasi yang diduga terkena dampak pertambangan.

Untuk dapatkan informasi apakah konsentrasi merkuri dalam air dari ketoga lokasi, yaitu hilir, muara dan kolam memiliki perbedaan secara signifikan, maka berikut ini disajikan ringkasan Anava A dalam tabel 3.

Berdasarkan data pada tabel 3 menunjukan bahwa konsentrasi merkuri $\mathrm{Hg}$ dalam sedimen dari ketiga lokasi adalah tidak berbeda secara signifikan. Namun apabila diuji lanjut menggunkan uji t maka untuk sedimen di lokasi kolam dengan muara serta kolam dengan hilir berbeda secara signifikan. Untuk lebih jelasnya, perbedaan konsentrasi merkuri dari ketiga jenis sedimen dapat dilihat dalam gambar 2 berikut. 


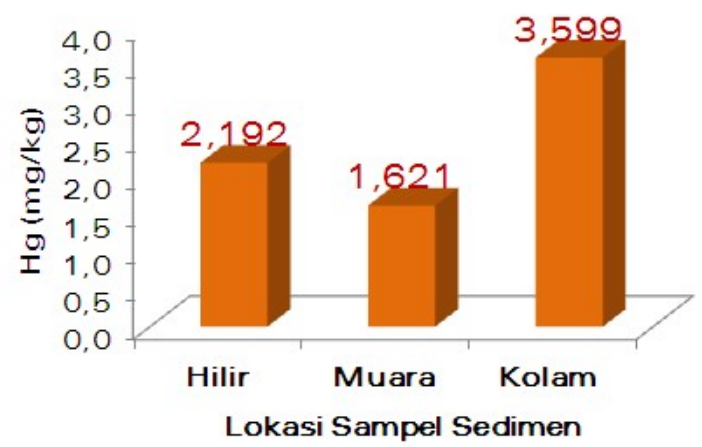

Gambar 2. Histogram konsentrasi $\mathrm{Hg}$ dalam sedimen

Berdasarkan histogram konsentrasi merkuri dalam sedimen pada gambar 3 menunjukan adanya perbedaan nilai, dimana sedimen kolam menunjukan konsentrasi $\mathrm{Hg}$ tertinggi. Beberapa hal yang menyebabkan perbedaan ini antara lain $\mathrm{pH}$ tanah, kandungan karbon organik total (asam humat dan fulvat) [21]. Tingginya merkuri dalam sedimen kolam disebabkan oleh kemungkinan tingginya karbon organik dari hasil limbah rumah tangga. Selain itu itu adanya koloid dalam sedimen juga memungkinkan tingginya akumulasi merkuri dalam sedimen [22],[[23], [10],[24],[25],[26]

\section{KESIMPULAN}

Kesimpulan yang diperoleh menunjukan bahwa distribusi konsentrasi merkuri baik dalam air mupun sedimen di lokasi wisata Loang Baloq bervariasi. Konsentrasi merkuri dalam air antara kolam antara $0,0110 \mathrm{~s} / \mathrm{d} 0,0310 \mathrm{mg} / \mathrm{L}$, air sungai hilir sebesar $0,0082 \mathrm{~s} / \mathrm{d} 0,0254 \mathrm{mg} / \mathrm{L}$ dan di muara sebesar $0,0004 \mathrm{~s} / \mathrm{d} \quad 0,0179 \mathrm{mg} / \mathrm{L}$. Konsentrasi merkuri dalam sedimen kolam antara 2,560 s/d $4,542 \mathrm{mg} / \mathrm{kg}$, sedimen sungai hilir sebesar 1,668

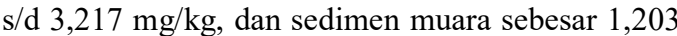
$\mathrm{s} / \mathrm{d} 2,039 \mathrm{mg} / \mathrm{kg}$.

\section{DAFTAR PUSTAKA}

[1]. Clarkson, T.W., M.D. Laszlo Magos dan G.J. Myers. 2003. The toxicology of mercury current exposures and clinical manifestations. N Engl J Med.349: 1731-1737.

[2]. Dickman, M.D., dan K.M. Leung, 1998. Mercury and organochlorine exposure from fish consumption in Hong Kong. Chemosphere, 37: 991-1015.

[3]. Sumarlan, I., \& Alfarisa, S. (2018). Penentuan Nilai Ketidakpastian Analisis Merkuri (Hg) Pada Daun Singkong Menggunakan Metode Solid Sampling Atomic Absorption Spectrophotometry. Jurnal Pijar Mipa, 13(2), $147-150$

[4]. Niazi, A. A. Aziz dan M. Ramezani. 2008. Simultaneous spectrophotometric determination of mercury and palladium with
Thio-Michler's Ketone using partial least squares regression and orthogonal signal correction. Spectrochimica Acta Part A: Molecular and Biomolecular Spectroscopy, Volume 71, Issue 3:1172-1177

[5]. Sukib, S., \& Mutiah, M. (2016). Eliminasi Gangguan Matriks Dalam Analisis Merkuri Hg Sebagai Senyawa Kompleks Thio Michler's Keton Secara Spektrofotometri. Jurnal Pijar Mipa, 11(1).

[6]. Ramalhosa, E., S.R. Segade, dan A. Duarte. 2011. Monomethylmercury behaviour in sediments collected from a mercurycontaminated lagoon. Intern. J. Environ. Anal. Chem. Vol. 91, No. 1: 49-61

[7]. Miller, J.C. dan J.N. Miller. 1991. Statistika Untuk Kimia Analitik. ITB, Bandung

[8]. Gehauf, B. dan J. Goldenson. 1950. 4,4'Bis(dimethylamino)thiobenzophenone as reagent for mercury and certain other metals. Anal. Chem., 22 (3): 498-499

[9]. Cheng, K.L dan L. Goydish. 1966. 4,4'Bis(dimethylamino)thiobenzophenone as a sensitive reagent for mercury and palladium. Microchemical Journal, Volume 10, Issues 1$4: 158-170$

[10]. Babiarz, C.L., Hurley, J.P., Hoffmann, S.R., Andren, A.W., Shafer, M.M., Armstrong, D.E., 2001. Partitioning of total mercury and methylmercury to the colloidal phase in freshwaters. Environ. Sci. Technol. 35, 47734782 .

[11]. Gray JE, Theodorakos PM, Bailey EA, Turner RR. Distribution, speciation, and transport of mercury in stream-sediment, stream-water, and fish collected near abandoned mercury mines in southwestern Alaska, USA. Sci Total Environ 2000;260:21-33.

[12]. Loredo J, Petit-Dominguez MD, Ordonez A, Galan MP, Fernandez-Martinez R, Alvarez R, Rucandio MI. Surface water monitoring in the 
mercury mining district of Asturias (Spain). $J$ Hazard Mater 2010;176:323-32.

[13]. Horvat M, Nolde N, Fajon V, Jereb V, Logar M, Lojen S, Jacimovic R, Falnoga I, Qu LY, Faganeli J, Drobne D. Total mercury, methylmercury and selenium in mercury polluted areas in the province Guizhou, China. Sci Total Environ 2003;304:231-56.

[14]. Qiu GL, Feng XB, Wang SF, Fu XW, Shang LH. Mercury distribution and speciation in water and fish from abandoned $\mathrm{Hg}$ mines in Wanshan, Guizhou province, China. Sci Total Environ 2009;407:5162-68.

[15]. Zhang H, Feng XB, Larssen T, Shang LH, Vogt RD, Rothenberg SE, Li P, Zhang H, Lin $Y$. Fractionation, distribution and transport of mercury in rivers and tributaries around WanshanHg mining district, Guizhou province, southwestern China: Part 1-Total mercury. Appl Geochem 2010a; 25:633-41.

[16]. Wang W, Driscoll CT. Patterns of Total Mercury Concentrations in Onondaga Lake, New York. Environ Sci Technol 1995;29:2261-6.

[17]. Berzas Nevado JJ, Garcia Bermejo LF, Rodriguez Martin-Doimeadios RC. Distribution ofmercury in the aquatic environment at Almaden, Spain. Environ Pollut 2003;122:261-71.

[18]. Biester H, Gosar M, Muller G. Mercury speciation in tailings of the Idrija mercury mine. J Geochem Explor 1999;65:195-204.

[19]. Covelli S, Faganeli J, Horvat M, Brambati A. Mercury contamination of coastal sediments as the result of long-term cinnabar mining activity (Gulf of Trieste, northern Adriatic sea). Appl Geochem 2001;16:541-58.

[20]. Suchanek TH, Cooke J, Keller K, Jorgensen S, Richerson PJ, Eagles-Smith CA, Harner EJ, Adam DP. A Mass Balance Mercury Budget for a Mine-Dominated Lake: Clear Lake, California. Water Air Soil Pollut 2009;196:5173.

[21]. Haitzer, M., Aiken, G.R., Ryan, J.N., 2002. Binding of mercury(II) to dissolved organic matter: the role of the mercury-to-DOM concentration ratio. Environ. Sci. Technol. 36, 3564-3570.

[22]. Zizek S, Horvat M, Gibicar D, Fajon V, Toman MJ. Bioaccumulation of mercury in benthic communities of a river ecosystem affected by mercury mining. Sci Total Environ 2007;377:407-15.
[23]. Domagalski, J.L., 1998. Occurrence and transport of total mercury and methyl mercury in the Sacramento River Basin, California. $J$. Geochem. Explor 64, 277-291.

[24]. Bloom, N.S., Watras, C.J., Hurley, J.P., 1991. Impact of acidification on the methylmercury cycle of remote seepage lakes. Water Air Soil Poll. 56, 477-491.

[25]. Choe, K.Y., Gill, G.A., Lehman, R., 2003. Distribution of particulate, colloidal, and dissolved mercury in San Francisco Bay estuary. 1. Total mercury. Limnol. Oceanogr. $48,1535-1546$.

[26]. Guentzel, J.L., Powell, R.T., Landing, W.M., Mason, R.P., 1996. Mercury associated with colloidal material in an estuarine and an openocean environment. Mar. Chem. 55, 177-188. 